\title{
Mission as Hospitality: Imitating the Hospitable God in Mission, E. L. Smither
}

Cascade. 2021. Eugene, Or: viii + pp. 137.

ISBN 978-1-7252-5731-3

\section{Reviewed by Graham A Duncan}

https://orcid.org/0000-0002-2583-1914

Department of Systematic and Historical Theology, Faculty of Theology and Religion University of Pretoria

graham.duncan@up.ac.za

This book provides a sensitive though clear wake-up call to South Africans in the midst of our current and ongoing demonstrations of xenophobia, which have caused so much angst to foreign nationals living within our borders. It also provides a timely reminder of our obligations to offer hospitality during a global pandemic, when our Gospel expressions had been turned upside down by enforcing isolation and social distancing as protective measures. Hospitality is an authentic approach to ministry.

Its inspiration comes from the Islamic world of hospitality-making room for others, especially strangers, giving them a place of acceptance where we move from xenophobia to philoxenia; from fear to friendship. The interfaith perspective is a significant missionary activity. It is integrated in God's mission because it reaches out in a movement towards reconciliation. The book consists of six chapters with a focus on hospitality: mission as hospitality in the Old Testament; the New Testament; at the Lord's table; in the work of missionary monks; contemporary models; and reflections and practice.

The Old Testament chapter offers the parameters of a mission of hospitality which is inclusive, welcoming God or angels, bound in a covenantal relationship, a religious duty that can help overcome vulnerability, and a gift God offers in order that the recipients can help others.

The New Testament chapter demonstrates incarnational mission; Jesus is the public and spiritual host in public spaces in which receiving hospitality is used as a stimulus for gospel proclamation. Jesus received the unwelcome (those outside the social circle and gentiles). On p.44, Rosaria Butterfield is quoted: "Jesus dined with sinners, but he didn't sin with sinners. Jesus lived in the world, but he didn't live like the world." And

\section{UNISA $\cong$}




\section{Duncan}

Mortimer Arias describes this early expansion of the church as "evangelization by hospitality." The exercise of hospitality is not just a casual, social affair. It has deep spiritual import

The Last Supper, which might be described as the disciples' graduation dinner, has the added dimension of the promise enshrined in an eschatological meal, where hospitality is demonstrated on Word, sacrament and discipline (as Christian nurture) - the three marks of Reformed Christianity. Hospitality has a sacramental quality.

In Early Christian teaching all divisions are broken down (well in advance of them being ruthlessly reinstated by the institutional church!). Hospitality becomes the centre of worship. It is an act of remembrance-foundational to Christian memory (p.69).

Hospitality was a central feature of many monastic movements where contemplation and service were complementary. Basil of Caesarea was the first to promote monastic missions where active mission was viewed as superior to the contemplative life. Celtic monks were particularly active in this respect.

Contemporary models of missionary hospitality are the subject of chapter 5, e.g., the L'Abri Fellowship, radically ordinary hospitality, and missional communities (Soma communities). Much of this resonates with African hospitality, but then, is this not a characteristic of the non-Western world?

Chapter six turns the focus to the practicalities of offering hospitality in the contemporary global context.

A considerable part of this text offers a helpful and insightful historical survey of hospitality, which was grounded in mission even if the church was not aware of this. Throughout, the author supports his survey with critical examples. We learn here that meals, with all the opportunities they present for in-depth listening and sharing, represent and embody the meaning of mission. Hospitality facilitates incarnational ministry that leads to authentic evangelism, discipleship, church planting and pastoral care.

I strongly recommend this book for study and action with all faith communities, for here we have much to learn from one another about God's plan to reconcile the world to Godself. 